\title{
SEMANTICS OF REFERENCE WORDS IN MALE AND FEMALE SPEECH
}

\author{
Kuchimova P.T.
}

Lecturer, Journalism And Mass Communications University Of Uzbekistan, Uzbekistan

\section{ABSTRACT}

The culture of communication between women and men is unique. A lot of linguistic work has been done on various features of their speech, and in some countries, women's speech has become a separate study. The article analyzes the reference words of men and women.

KEYWORDS: - Reference words, forms of reference words, masculine reference words, feminine reference words, semantics.

\section{INTRODUCTION}

While the roles of men and women, who have belonged to the same species for millennia, differ in terms of their place in society, the two genders also differ linguistically. In particular, there are significant differences between the two genders in the use of linguistic and non-linguistic units, as well as in the use of linguistic and non-linguistic units. Many linguistic and non-linguistic units are genderspecific because they belong to a particular gender. The emphasis on logic is very active in women, and the pauses are much shorter than in men. The lexemes used in women's and men's speech also have a special meaning. The process of language renewal is more quickly accepted by men than by women, and new scientific and professional lexemes are more and more active in men's speech.
Women also try to avoid it in formal communication, making effective use of neologisms in daily life.

Because women are naturally sophisticated, they also use attractive and colorful lexemes, personal expressions, and positively colored words in conversations. The subject of the conversation is a bit exaggerated. Emotional states: We can observe mental and physiological processes in them, such as surprise, joy, fear, hatred, and sadness.

The culture of communication between women and men is unique. There has been a great deal of linguistic work on the different features of their speech, and in some nations women's speech has emerged as a separate study. This distinction is important and plays an important role in the culture of communication. Recent research in Uzbek linguistics has shed little light on this. In particular, 
CURRENT RESEARCH JOURNAL OF PHILOLOGICAL SCIENCES 2(11):

158-161, November 2021

DOI: https://doi.org/10.37547/philological-crjps-02-11-34

ISSN 2767-3758

(C)2021 Master Journals

Crossref do

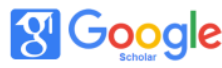

Accepted $25^{\text {th }}$ November, 2021 \& Published $30^{\text {th }}$ November, 2021

this can be seen in S. Muminov, Sh. Iskandarova's research. Gender-specific communication is an important part of the study of sociolinguistics. When analyzing forms of appeal in terms of gender, it is necessary to analyze the forms of appeals used in the speech of men and women, as well as the forms of appeals applied to men and women.

Reference forms are divided into two types depending on whether the object is clear or ambiguous:

a) abstract reference forms (hey, hoy, sen, siz);

b) specific application forms.

In this type of address, nouns, nicknames, nicknames, lexical, nominative units denoting human characteristics serve as a form of address. "अरे बाबू! तुमने तो अभी तस्वीर शुरू भी नहीं की, यह कागज़ तो अभी कोरा ही है।" _अभी मैं तुम्हें समझने की कोशिश कर रहा हूँ। [कृश्र चन्दर, 2013: 20]"

Translation:

Ey bobu! Siz suvratni hali boshlamabsiz ham-ku, qog'oz oppoqligicha turibdi. - Hozircha seni tushunishga harakat qilayapman [Krishn Chandar, 2011: 12].

[Hey grandpa! You haven't started painting yet, but the paper is still white. - I am still trying to understand you]

\section{Analysis}

The word "Babu" is used in the Indian subcontinent as a sign of respect for men. In some cultures, babu means to treat a loved one with kindness. The suffix "ji" is added. Babuji is formed. The word is used in northern and eastern India to honor his father. Babuji can also be used as a term of respect for any respectable elder or man. In some Indian landowners, the title Babu or Babu Shri was used by its rulers. In many kingdoms, members of the royal family and relatives of kings also used the name. Babu is also used as a suffix to a person's name when he calls out his name, for example, "Mohan babu, can you come here, please?". In Bengali, the word babu or babushona is more widely used, meaning baby, especially young children. It is clear from this sentence that an abstract and concrete form of appeal was used. That is, the form of the appeal is abstract and the appeal of the chapter is concrete and it is applied to men.

Among the nouns used in masculine, the lexical units that express the paternal sema are especially recognized. It is usually disrespectful to call a father by his first name when he is approached by close family members. Addressing her husband as father, grandfather, great-grandfather, great-grandfather, great-great-grandfather, such as "father of children", "respect", "seniority" and "kinship ".

There is no language without meaning and understanding. That's the way people think and act. Otherwise, language cannot fulfill its function, it performs its main function only because of meaning and concepts, and any message, information is formed and emerges on the basis of meaning and understanding. Man and society itself exist because of meaning and concepts, language and speech. If "there is no common and understandable language for all members of society, production in the society will stop, life as a society will end and it will disintegrate" [Kurbanova M., 2014: 43]. This means that language also plays an important role in the formation of man and society, and therefore many scholars believe that "one of the necessary components in the formation of man and society was the formation of language and speech."

The different forms of the content of the message the combination of meanings such as joy, fear, anger, compliment, hatred - depend primarily on the attitude arising from the social environment and circumstances. Language, on the other hand, is the means by which this relationship can be realized in its original form. 
CURRENT RESEARCH JOURNAL OF PHILOLOGICAL SCIENCES 2(11):

158-161, November 2021

DOI: https://doi.org/10.37547/philological-crjps-02-11-34

ISSN 2767-3758

(C)2021 Master Journals

\section{Crossref do) 81 Google}

Accepted $25^{\text {th }}$ November, 2021 \& Published $30^{\text {th }}$ November, 2021

Usually, when talking about the application form, the listener is meant first. In fact, this is the second object of the appeal. The listener, both as a sociological object and as a linguistic object, is completely compatible: the listener is you, that is, as a social person, he is different. The logicalgrammatical formation of this expression in speech is also different, that is, the second person, singular or plural. It is the social opposite - the grammatical second person is the opposite of the speaker, who is the social figure as the receiver of thought - the speech and the thought expressed through it is directed to him.

Based on the above, let's focus on the examples in Krishan Chandar's novel A Thousand Lovers for a Girl. In the course of the research, the words used in the play were used for men and for women.

References to the men in the novel:

बचपन ही से उसे चित्रकला का बड़ा चाव था; मगर उसके पिता रायबहादुर श्री गंगासहाय डिप्टी इन्सपेक्टर जनरल जेलखाना थे और यह विभाग एक तरह से उनका अपना ही था और ज़माना अंग्रेज़ों का था। [कृश्र चन्दर, 2013: 37]

Translation:

Bolaligida rassomlikka qattiq qiziqardi, biroq otasi roybahodur Shri bo'lgani bilan zamona tizgini inglizlar qo'lida edi [Krishn Chandar, 2011: 33].

[As a child, he was passionate about painting, but his father, Shri, was in control of the modern world]

Analysis: Ray is a historical title used in reference to rulers. Used by many rulers and princes on the Indian subcontinent. Telugu version Rao. During the Mongol rule, the words Raja or Rai were added to a person's name when giving the title to a Hindu or Sikh chief. The Mongols inherited the title from the sultans of Delhi. Rai applies to men, Rani applies to women.

Ray Sahib and Rai Bahadur were honorary titles for leadership. They were given enormous power and their feudal property was equal to that of local rulers. The word Sri appeal given above is also used in a respectful way. It is a powerful expression of respect for human beings. The word applies to both women and men.

"नहीं भाई!" -लाची ने बड़ी सख्ती से कहा- "इस मनीआर्डर को वापस कर दो, फौरन वापस कर दो!" -यह कहकर लाची ने बड़ी तेज़ी से दरवाज़ा अन्दर से बन्द कर लिया।[कृश्र चन्दर, 2013: 41]

Translation:

Yo'q, og'a, - dedi Laychiy g'oyat jiddiy ohangda, - bu pulni qaytarib yuboring, darrov qaytarib yuboring. - Shunday deb Laychiy shiddat bilan eshikni ichkarisidan yopib oldi.[Krishn Chandar, 2011: 36]. ["No, brother," said Laichi in a very serious tone, "return the money, send it back immediately." - So Laichi quickly closed the door from the inside.]0

Analysis: The word भाई - bhāī in the sentence is a specific form of appeal. Its literal translation is brother. The word is used in kinship, and it is also used to refer to a stranger.

"ऐनकवाले बाबू एक आना, छातेवाली बीबी एक आना, दाढ़ी वाले सरदारजी एक आना...." जैसे वह भीख न माँग रही हो, क्यू में खड़े हुए लोगों को नीलाम कर रही हो। 'सारा माल लुटा दिया है एक आने में!'

Translation:

Hoy ko'zoynak taqqan janob, bir anna xayr qiling! Hoy soyabon tutgan xonim, bir anna xayr qiling! Hoy soqolli sardorjiy bir anna xayr qiling.

[Hey, glasses guy, donate some money! Hey lady holding an umbrella, donate money! Hey bearded captain give money.]

Analysis: Mr. application form does not require the name or surname of the interviewee. Older people, men, peers or elders are referred.

From the above examples, we can see that the types of words used in the examples discussed in Krishan Chandar's novel A Thousand Lovers for a Girl have been explored. According to them, similarities were found to mean social status, affection, respect, and title, and gender use was separated. 
CURRENT RESEARCH JOURNAL OF PHILOLOGICAL SCIENCES 2(11):

158-161, November 2021

DOI: https://doi.org/10.37547/philological-crjps-02-11-34

ISSN 2767-3758

(C)2021 Master Journals

Crossref dof 81 Google

Accepted25 $5^{\text {th }}$ November, 2021 \& Published 30 ${ }^{\text {th }}$ November, 2021

\section{REFERENCES}

1. Kurbanova M. Genderolinguistic research as a new paradigm // TA, 2014. №2.

2. Safarov Sh., Boymirzaeva S. Gender Linguistics and Text Research // Foreign Philology, 2006. №4.

3. Krishan Chandar. I fell in love with a girl. (Translated by Amir Fayzullaev) // World of Literature (3). - Tashkent: Uzbekistan, 2011.

4. कृश्न चन्दर। एक लड़की हज़ार दीवाने। नई दिल्ली 2013.

5. Akhmanova O.S. Dictionary of linguistic terms. - M., 1960. 